\title{
Chris Synodinos
}

\section{Jerome's Contra Johannem and ps.-Basil's De con- solatione in adversis on resurrection and disability Hieronimov Contra Johannem in ps.-Bazilijev De con- solatione in adversis o vstajenju in telesnih okvarah}

Abstract: This paper concerns disability and bodily resurrection, the latter being a topic that has bemused Christian theologians from the beginning. Specifically, this paper concerns Jerome's treatise Contra Johannem, directed against John of Jerusalem, a putative Origenist, and De consolatione in adversis attributed to ps.-Basil. The author of Cons. was concerned with the nature of the resurrected body regarding a particular class of disabled people, viz., an audience of lepers, whereas Jerome focuses on the resurrection of the flesh in general. There is some evidence to suggest Cons. is somehow linked, even if implicitly and indirectly, to the Origenist controversy, which primarily concentrates on the nature of the resurrected body. The two prevailing related themes in Cons., to wit, leprosy, and the flesh's resurrection, relate to the body. It is interesting that the only two codices containing this work also contain Jerome's epistle Contra Johannem. These two works occur again in the editio princeps (Paris 1528). The significance of this thematic connection remains to be explained, and St. Jerome's influence clarified.

Keywords: affliction, leprosy, redemptive suffering, the resurrection of the flesh, spiritual body, Origenism, resurrection body, garment of glory, garment of brilliance

Povzetek: Članek obravnava temo telesne okvare in telesnega vstajenja, pri tem pa je telesno vstajenje področje, ki je krščanske teologe zaposlovalo že od začetka. Natančneje, ta članek zadeva Hieronimovo razpravo Contra Johannem, ki je usmerjena proti Janezu Jeruzalemskemu, domnevnemu origenistu, in proti delu De consolatione in adversis, pripisano Ps.-Baziliju. Avtor De consolatione se ukvarja z naravo vstalega telesa glede na razred telesne okvare, namreč gobavcev, medtem ko se Hieronim osredotoča na vstajenje mesa na splošno. Obstaja nekaj dokazov, ki kažejo, da je De consolatione povezan, tudi če le implicitno in posredno, z origenistično polemiko, ki se ukvarja predvsem z naravo vstalega telesa. Obe prevladujoči povezani temi v De consolatione, gobavost in 
vstajenje mesa, zadevata telo. Zanimivo je, da edina kodeksa, ki vsebujeta to delo, vsebujeta tudi Hieronimovo pismo Contra Johannem. Obe deli ponovno nastopata v editio princeps (Pariz 1528). Pomen te tematske povezave je treba še pojasniti, razjasniti pa kaže tudi vpliv sv. Hieronima.

Ključne besede: bolezen, gobavost, odrešitveno trpljenje, vstajenje mesa, duhovno telo, origenizem, vstajenje, oblačilo slave, oblačilo sijaja

This paper concerns disability and bodily resurrection, the latter being a topic that has bemused Christian theologians from the beginning. Specifically, this paper concerns Jerome's treatise Contra Johannem Hierosolymitanum ad Pammachium (= Contra Johannem), which is directed against John of Jerusalem, a putative Origenist, and De consolatione in adversis (= Cons.) attributed to ps.-Basil (PG 31, 1687C-1704B). The latter treatise, a work transmitted in Latin, was the subject of my doctoral dissertation, in which I argued that St. Radegundis of Poitiers (c. 520-587) was the author (Synodinos 2010). The author of Cons. was concerned with the nature of the resurrected body concerning a particular class of disabled people, viz., an audience of lepers, disabled, whereas Jerome focuses on the resurrection of the flesh in general. There is some evidence to suggest Cons. is somehow linked, even if implicitly and indirectly, to the Origenist controversy, which primarily concentrates on the nature of the resurrected body. The two prevailing related themes in Cons., to wit, leprosy, and the flesh's resurrection, relate to the body. ${ }^{1}$ It is interesting that the only two codices containing this work also contain Jerome's epistle Contra Johannem. These two works occur again in the editio princeps (Paris 1528). The significance of this thematic connection remains to be explained, and St. Jerome's influence clarified.

The preacher of Cons., a sermon in the diatribe style, is confronted with a composite task: an audience of lepers needs to be comforted and guided, but above all, it needs to be set straight on the involvement of Providence in their suffering. Moreover, this audience must be corrected in their distorted speculations on the state of their resurrection body as conditioned by their dreadful disability. This audience see in their suffering a penalty of sin, a retribution occasioned by their conduct, and construe their affliction not only as a mark of divine judgment but of divine abandonment as well. In addition, they compound their misfortune by taking it a step further to the level of resurrection and everlasting life, apparently maintaining that the affliction under which they labour in the present life will somehow prevail beyond death and condition the state of their resurrection body as well and that they will rise as lepers on the appointed day for all eternity (Cons., PG 31, 1700A). Notwithstanding, there is always the possibility that they qualify the view they entertain on the kind of resurrection they expect for themselves viz., that they will rise as lepers in everlasting life - that they hold it to be valid only if the resurrection is construed as resurrection in the flesh, and that accordingly, on account of this qualified belief, they have already endorsed a different type of resurrection theory by the time they are being addressed. However, this may be,

For an excellent general reflection on suffering related to flesh, see Mensch 2019. 
detecting this subliminal meaning cued by the audience's sentiments of profound dejection and arising from it, the preacher endeavours earnestly in her sermon to maintain a balance between alleviating pain and eradicating implicit disbelief.

It is unclear how the lepers concluded by endorsing such a grim prospect for their resurrectional future or by whom or what they were prompted to do so. Nonetheless, two preliminary relevant facts can be gleaned with relative certainty from the preacher's address. The first is that their distorted perception of the resurrection seems alarming enough to warrant the preacher's intervention in matters of redemptive significance. The second fact is the vague reference to some party whom the preacher implicates in her audience's endorsement of contorted eschatological principles:

„Non te ergo dilectissime, corporis damna contristent, sed quidquid dominus miserit, gratulanter et viriliter suffer /... / Novi enim quosdam - maxime eos qui leprae macula fuerint corde asparsi - in tantum disperationem pro hac plaga venire, ut putent se omnino destitutos esse a domino.

[Let not afflictions of the body grieve you, then, beloved, but whatever God has sent firmly and joyously endure /... / For I know that some-clearly those who are dear to me, tainted as they with their taint of leprosy - have fallen into such despair on account of this misfortune that they think the Lord has completely forsaken them.]« (1698A-B $)^{2}$

Here, dilectissime presumably refers to the audience, while quosdam appears to involve a different group. The relation and interactions between the audience and the unnamed party, which the fantastic interlocutor represents, ${ }^{3}$ are not specified. True, when lashing out at the fantastic interlocutor in brisk, typically diatribe style, indicting him on charges of arbitrary, scripturally unfounded eschatological interpretation of the resurrection, the preacher may by gently censoring the audience as well by indicting it indirectly on the same charge. Nevertheless, the imaginary interlocutor here is more of an interlocutor in absentia than an imaginary one, since, despite the indefinite pronoun in the apostrophe quisquis ille es, "whomever you may be, " with which the fantastic interlocutor is addressed, the preacher has in mind a particular group of people, possibly other than the audience, some party she knows of with whom the audience share the same affliction and with whose aberrant tenets they have blurred their belief in the resurrection.

Conversely, the unnamed party here typified by the fantastic interlocutor may, for all practical purposes, stand for the audience, whom the speaker advisedly

\footnotetext{
All translations are mine unless otherwise stated.
}

3 The diatribe has been generally defined as a hybrid between declamation and dialogue. The most fundamental feature of the diatribe's dialogic element in its fully developed form is the imaginary, or fantastic, addressee, a fictitious interlocutor who interrupts the speaker's disquisition, in general as the mouthpiece for the common opinion, and may have a succinct dialogical exchange with the speaker. As a rule, the interruption of the fictitious interlocutor amounts to an objection or a false conclusion, stated in conformity with a set of formal features. The speaker's reply to the fictitious interlocutor likewise follows similar formal patterns. 
does not name out of compassion and courtesy in a kind of politeness strategy. From the meagre facts presented in this homily, complicated as they are by the preacher's diatribe style, the relation of the two parties cannot be conclusively ascertained. What matters, however, is the twisted eschatological ideology here revealed: the preacher is likely aware of the fact that the corollary of such extravagant dogmatics may be for the audience to persist in the idea of the resurrection per se while dropping that of the resurrection of the flesh in the long run-that is, if they have not done so already as previously stated. For the lepers must realize that the possibility for the disease to spill over into the life to come can potentially be afforded only by its clinging on to flesh-in this case, to flesh made eternal-in other words, by encroaching on the fleshy materiality of their resurrected bodies.

Neither is it clear whether they hold their views unconditionally or consider them by qualifying them somehow. The preacher's entreaty, ne velis, etc. (1699A), indeed allows for both of these alternatives. As regards the second of the two, the audience may, for instance, have already opted for some spiritual bodily resurrection after being convinced of their resurrection in leprosy if belief in the resurrection were to be construed as the resurrection of the flesh. The possibility of such reasoning on the part of the audience may again be detected in yet another of the preacher's attempts at allaying her audience's resurrectional fears by urging them to suppress their mortiferam suspicionem, their "spiritually deadly notion, laden with mistrust" (1700A). It is evident that in the audience's terrified minds flesh made eternal could somehow be represented as affording a chance - however slim - for the disease to spread into life everlasting by feeding on their fleshy limbs in their resurrection status; and that the nervous shock sustained in consequence of this dreadful prospect could easily lead them to reject the resurrection of the flesh unreservedly altogether. Accordingly, it would somehow seem that in this audience's case, the spillover of the disease into the next world hinges upon the fleshy materiality of the body and that this spillover could be checked by removing the flash from the picture altogether.

Nevertheless, the survival of the body in its fleshy materiality after attaining to a resurrection status is a highly-charged, controversial issue that plagued Christian dogmatics during the Origenist crisis; and the question is if the extravagant beliefs entertained by the disabled audience of the current sermon are somehow connected with Origenist views, as seems to be indicated at least at the corollary level. If this is so, and if the affinity claimed between Origenist doctrines and this audience's set of beliefs is tenable - as seems to be the case in light of the implications of such beliefs for the audience in the manner previously analyzed - then some contextual relations tentatively identified between this sermon and some of the literature involved in the Origenist controversy would appear to stand on more solid ground. One such instance worth investigating would be the case of affinities between Cons. strategies and ideas and those occurring in Jerome's Contra Johannem. And this possible connection between Cons. and Contra Johannem, at any rate, would tend to indicate that the coincident occurrence of both these works in the extant witnesses, MSS Tours 281 and Caen 34 (373), may be the result of a 
deliberate decision made by some party involved in these witnesses' production based on the common ground these two pieces share in certain aspects. Such a claim is undoubtedly attractively plausible for MS Caen 34 (373) for one in that Caen is already a selective apograph of Tours, the oldest extant witness, but it can certainly be true of Tours itself as well and possibly of some antecedent witness or witnesses reflected in Tours. Furthermore, to say that Radegundis of Poitiers was likely reading the Contra Johannem among other sources of inspiration in composing this sermon seems to imply that the preacher herself may have detected Origenist overtones in her audience's interpretation of and outlook on the resurrection of the flesh.

Of all the scriptural figures summoned into action in the course of this sermon, Job is the most prominent concerning his importance in exemplifying the circumstances and ideas that the preacher has set herself the task to get across. Job pre-eminently typifies and embodies the suffering of the righteous, almost in a Stoic fashion, as vir philosophicus (Cons., PG 31, 1694A), and scriptural segments of exchanges between Job and his wife are used to cast them both in character roles of lively, diatribe-like sketches. Regardless of the audience's unknown actual choice of a resurrectional model at the time they are being addressed, that this choice is conditioned by their understanding of the resurrection of the flesh as it pertains to them and that, accordingly, their cacodoxy consists precisely in that understanding is manifest from some of the preacher's appeals (1702B). Job is assigned an essential role in the preacher's endeavour to refute this cacodoxy. $\mathrm{He}$ is called upon to attest to his belief in the resurrection, which he construes as resurrection in his flesh (1701B). Because he bears witness to his conviction while he is entirely in thrall to the disease and his flesh is infected, the preacher infers that he hoped to rise again healed and cleansed of his affliction and that it was precisely this expectation that sustained him in his ineffable suffering (1701A).

However, the same strategy of citing this very passage and explicating it by way of drawing the very same inference to the advantage of the argument at hand likewise occurs in Jerome's Contra Johannem, in the section arguing the resurrection of the flesh (Contra Johannem, PL 23, 373C-389A). Nearly two-thirds of the ten scriptural passages cited in treating the Cons. variation of the same topic in the dedicated portion of this work, including the three longest ones and critical to the treatment of the resurrection of the flesh in Cons., namely, Job 19,25-27; 1 Cor 15,35-38, and 1 Cor 15,42-44, occur in Contra Johannem as well. ${ }^{4}$ Of these, 1 Cor 15 is a crucial text, fundamental to establishing doctrinal realities respecting the resurrection of the dead. It »contains the fullest treatment of the resurrection /... / found anywhere in the Bible« (Hoekema 1979, 247). The fourth section of 1 Cor 15,35-50, from which the passage cited in both Contra Johannem and Cons. is derived, contains ideas that had admitted from the outset of manifold interpretations, on which fed the folly of all heretical sects in their disputes with the Church

4 Two Matthew passages that appear to be implicitly mutually linked with reference to the common ground Cons. and $C J$ share in treating the resurrection body will be discussed in more detail later. Cf. also Scobie 2011. 
on matters of resurrection, on Irenaeus's evidence (Swete 1908, 93). Thus, it does not come as a surprise that 1 Cor 15,35-38, occurring in Contra Johannem and in Cons., is used in both these works in response to what is perceived as a doctrinal perversion of the parties addressed.

Moreover, as regards the particular citation of Job's passage in both works, Job is styled as athleta Ecclesiae in Contra Johannem (PL 23, 382A), while in Cons. he is said "to strip naked for his contest as is the custom among athletes " [mos enim est athletarum ut ad certamen nudi procedant] (1694B). Besides Job, Jerome enlists help from Enoch and Elijah, who were assumed while being still in the flesh, to support his argument against the purported Origenism of John of Jerusalem. Enoch and Elijah are said to be presently »inhabitants of paradise " paradisi coloni) (Contra Johannem, PL 23, 381B), while in Cons., in a moving appeal to the frater, viz., the audience collectively addressed, the preacher urges him to become paradisi colonus by suffering patiently in this life (1699A). True, Enoch and Elijah do not feature in Cons. to suggest that, like athleta in Job, the designation paradisi colonus may imply an additional possible link between Cons. and Contra Johannem. However, the case of such link between these works is bolstered if the occurrence of the designations mentioned above in the Cons. diction is not regarded as a mere accident but as a silent incident of subconscious recollection of Jerome's text, peripheral to what appears to be the conscious borrowing of nearly the entire Bible of Cons. (1700A-1702C) from Contra Johannem for the reasons previously submitted. So far, then, we have discussed Job 19,25-27, and 1 Cor. 15,35-38, the two of the three longest Biblical quotations, which Cons. contains and shares with Contra Johannem regarding the resurrection of the flesh. In both works, we have posited that the Pauline passage and Job's testimony are solicited to evince the ultimately established doctrine of the Church on the resurrection of the dead, which is properly construed as the resurrection of the flesh. Accordingly, Cons. and Contra Johannem may be said to share: 1 . common doctrinal challenges respecting the resurrection of the flesh; 2 . the same strategy in using Job 19,25-27 and 1 Cor 15,35-38 to address issues arising from their respective challenges; 3 . the same end aimed at, namely, resolving eschatological distortions and ambiguities concerning the resurrection body in conformity with the ultimately established view of the Church.

In Cons. the lepers are promised to "put on a heavenly body" (caeleste corpus induere) (1702A-1702B), with the diction picking up on the outfit imagery of the Pauline passage - much like in Contra Johannem (PL 23, 381A). This, heavenly body', however, that the preacher promises her lepers in Cons. is not a new body, but - to judge from the Bible cited -their very same body, which, as understood in Job's statement, "/ shall be wrapped with my own skin and with my own flesh « [circumdabor pelle mea et /... / carne mea] (1701B), is shaped or transformed for the better: "in id ipsum corpus /.../ in melius conformari." (1701A ). It is called ,heavenly' in that it reflects the state proper for it to enter the ,heavenly kingdom' (regnum caeleste); ${ }^{5}$ but it is indubitably its old self - extinct flesh, desiccated bones

,Heavenly body' (corpus caeleste) seems to be a term suggested by 1 Cor. 15.40 , cited in both Cons. (PG 
and all (1702B) - revived to be converted, viz., to suffer a dramatic, enhanced qualitative change: in melius transformari (1702B). This change is manifested in the qualitatively new attribute of its resurrection state, viz., its ,heavenly splendour', claritate caelestium, an attribute also said to ,be worn', immortalis splendorem induere in everlasting life (1701B). The body that undergoes these changes in the resurrection is consequently time and again explicitly said in Cons. to consist of skin, flesh, and bones, modified for the better (1701B; 1702B). As regards the clothing trope referred to, immortalis splendorem induere, it must be observed that splendorem induere comes immediately next to immortalis - a predicative adjective indicating the state in which the transformed person will ,put on' their new corporeal attribute, to wit, their brilliance: "you will wear this brilliance when you are immortal." The textual proximity of the two notions, ,immortality ' and ,brilliance', suggests mutual concomitance, as if one is accessory to the other; or better still, as if this brilliance is the outward appearance of the idea or state of immortality embodied. Accordingly, the ,splendour' which is metaphorically ,put on' must be the ,splendour of immortality'. The attire imagery in Cons. is undoubtedly suggested by 1 Cor 15,53: "corruptibile hoc induerit incorruptionem, et mortale hoc induerit inmortalitatem « - »for this corruptible must put on incorruption: and this mortal must put on immortality, " cited in it as well as in Contra Johannem (Cons., PG 31, 1702A-B; Contra Johannem, PL 23, 381A). In Cons. the resurrection body is invested with the splendour of immortality or puts on brilliance in its immortal state; in Contra Johannem it wears the garment of immortality, which bestows glory on it (381A). Notwithstanding, a close conceptual affinity in imagery and key terms which is found between these two works in their respective explications of 1 Cor 15,53 cannot, as regards Cons., be explained by a coincident or spontaneous eagerness of the author to continue along the lines of the imagery of the common Pauline source - at least not entirely. Rather, in Cons., even if to some extent, this affinity needs to be considered in light of the other points of common interest that Cons. shares with Contra Johannem, as previously detailed. However this may be, a note should still be taken of the fact that in Cons. the term used to name the one property mentioned about a body clad in immortality as peculiar to it is ,brilliance' (splendor, claritas), while the related term in Contra Johannem is ,glory' (gloria). However, although, glory' in the Contra Johannem exegesis of 1 Cor 15,53 is a choice consistent with the Latin translation of Paul's Greek term $\delta$ ó $\alpha$ in 1 Cor 15,42-44 (378A), ,brilliance' or ,splendour', which occurs in Cons. instead, is not an inconsistent surrogate term for it - especially in light of the general tenor of Jerome's text.

The distance between the gloria of the resurrection body in Contra Johannem and the claritas of the same in Cons. is but a step. The claritas of the body in the

\footnotetext{
31, 1702A) and in Contra Johannem (PL 23, 379B). But the interpretation of corpora caelestia in CJ differs considerably from that found in Cons., except in one place in Contra Johannem, where Jerome's reference seems to be to an implied »heavenly body « construed in a way kindred to that found in Cons.; see Contra Johannem, PL 23, 381B, where Jerome's refers to the resurrection body as "domicilium [viz., corpus, supplied from Contra Johannem, PL 23, 381A] nostrum, quod de caelo est. [our dwelling which is from heaven]"
} 
latter work is implicit in the gloria of the former work. No further details are provided in 1 Cor 15,42-44 respecting the $\delta$ ó $\alpha$ of the resurrection body. Paul offers a better glimpse into the body's $\delta$ ó $\alpha$ yet to come, however, by specifying in Phil 3,21 that our bodies will be transformed in conformity with the body of the Lord's $\delta o ́ \xi \alpha(1 \mathrm{Jn} 3,2)$. Thus, practically in the same context, the self-same term $\delta$ ó $\alpha$ is used, now regarding the Lord's body (Phil 3,21), now about everybody else's (1 Cor 15,43$)$. As previously stated, Jerome selects gloria for the Greek $\delta$ ó $\alpha \alpha$ in his Latin rendition of 1 Cor 15,43 . This is the $\delta$ ó $\xi \alpha$ of our future resurrection bodies.

Notwithstanding, in Phil 3,21 he renders the self-same $\delta$ ó $\alpha \alpha$ of the original Greek by claritas. This is the $\delta$ ó $\alpha \alpha$ of the Lord's body, to which our bodies will conform. Clearly, in Phil 3,21 Jerome takes $\delta$ ó $\alpha \alpha$ as applied to Christ's body in its sense of ,dazzling radiance' or ,glaring splendour'. Thus in Jerome's understanding and terminology, the glory ( $\delta$ ó $\xi \alpha$ ) of the resurrection bodies of the righteous is not their own but the glory ( $\left.\delta \delta^{\prime} \alpha\right)$ of the Lord's body, viz., a glory manifested in brilliance (claritas), to which every resurrection body conforms. Then, since the resurrection body conforms to the glory of the Lord's body - which glory is brilliance (claritas) - the glory of the resurrection body must be likewise construed as brilliance (claritas). Accordingly, the gloria of the resurrection body in Contra Johannem and the claritas of the same, spoken of in Cons., amount to the same property or state. Moreover, Jerome construes the brilliance which the $\delta$ ó $\alpha$ of the Lord's body is taken to be in Phil 3,21 as selfsame with the dazzling splendour of the Transfiguration; for albeit this brilliance, to which the glory ( $\delta$ ó $\xi \alpha$ ) of our resurrection bodies conforms, is not further qualified in Phil 3,21, in Contra Johannem the glory of the resurrection body is likened to the glory of the Transfiguration; to wit, to the glory of the Lord's body, which Jerome construes as brilliance in Phil 3,21 and which is manifested as such par excellence in the Transfiguration episode. To be more specific, immediately following his discussion of 1 Cor 15,53 in Contra Johannem, Jerome goes on to rehearse questions touching the Transfiguration in its connection with the glory of the resurrection body. In so doing, he links the two transformations - that of the Transfiguration and that of the resurrection body - by way of a comparison involving the link-word ,glory' ("Sic et Dominus noster in monte transfiguratus est in gloria " [»in like manner, our Lord was likewise transfigured on the mountain «] Contra Johannem PL 23, 381A). The comparison is likely intended to take the connection to a deeper level, viz., to imply that the glory attending the Lord's transfigured body and clothes on Mt. Tabor is selfsame with the glory clothing the resurrection body upon the latter's investiture with the, garment (indumentum, or vestimentum) of immortality'. Jerome did hold that view, as documented in his commentary on Matthew: „Qualis futurus est tempore iudicandi talis apostolis apparuit /.../ certe transformatus est dominus in eam gloriam qua uenturus est postea in regno suo." (Hieronymus, In Mt 3 [PL 26, 121D-122A]) The likely reason for Jerome to construe the $\delta$ ó $\xi \alpha$ of the Lord's body in Phil 3,21 as claritas, and specifically as the claritas of the Transfiguration - viz., the radiant brilliance to which our resurrection bodies conform-is possibly the fact that Phil 3,21 finds ideal application in the Lord's assurance that the just will 
shine as the sun (Mt 13,43). In his promise, the Lord foretells a state of dazzling brilliance for the righteous, and if Phil 3,21 specifies that their bodies will conform to the $\delta$ ó $\xi \alpha$ of the Lord's body, that $\delta o ́ \xi \alpha$, whatever else it may be construed $a s^{6}$ it must be likewise construed as dazzling brilliance. For it is to the body of the Lord, whose "facies fulgebat sicut sol " (Mt 17,2), that need to confirm the bodies of those who »fulgebunt /.../ sicut sol « (Mt 13,43). Thus, Jerome's dazzling brilliance is not primarily understood as that which shone on Paul on the road to Damascus ${ }^{7}$ but that which attended Christ's body when transfigured.

The first of these two Matthew passages just cited occurs in Contra Johannem (PL 23, 381B: "Et facies eius, inquit, fulgebat sicut sol «), the second in Cons. (PG 31, 1700B: "Tunc, inquit, justi fulgebunt in regno Patris sui, sicut sol «). They are both cited in the context of the discussion involving the glory of the resurrection body, a context that both works share. Although not cited together in the pertinent sections of either work under discussion, these two passages are mutually evocative and complementary in the context shared by Cons. and Contra Johannem, as illustrated by discussing the term claritas regarding gloria in the latter work. This being the case in Jerome, it is reasonable to assume that these two passages should be likewise mutually complementary in Cons. and that although only Mt 13,43 is cited in it, Mt 13,43 is somehow evocative of Mt 17,2. In that sense, Mt 13,43, which is cited in Cons., seems to be an indirect reference to Mt 17,2, viz., to the splendour of the Transfiguration. The Cons. section discussing the bedazzling transformation experienced by the resurrection body is resplendent with such marvellous luminosity that one can think of no other episode more splendid in transcendent radiance to inspire and serve as a model (Cons., PG 31, 1700B: »justi fulgebunt /.../ sicut sol«; 1701B: »immortalis splendorem induere», the resurrection body, said to be clothed in brilliance in Cons. 1701B) - even if tacitly - besides the Transfiguration. Moreover, this uniqueness is that in a sermon in need of highlighting the changes suffered by the resurrection body in its transformation, the Transfiguration is the only scriptural epiphany that provides a glimpse into a mechanism of change witnessed and applicable to the transformation of the resurrection body. ${ }^{8}$ Such a tacit reference would account not only for the gloria and claritas connection in the context under discussion; it would likewise explain the ease with which someone aware of Jerome's terminology in Contra Johannem could shift to that found in Cons. and substitute claritas for gloria concerning the resurrection body as if these two terms were interchangeable. That they were so by the time the preacher of Cons. was delivering her sermon is documented. At least they were so in Hilary of Poitiers, ${ }^{9}$ who occupies a prominent place on Radegundis's reading list along with

6 Kennedy, for instance, observes that $\delta$ ó $\alpha$ in Paul »is always the outward expression of the spiritual life« $(1897,463)$.

7 Kennedy identifies this dazzling brilliance with that "which shone forth upon Paul from the risen Christ on the Damascus road« (Kennedy 1897, 464).

8 The episode involving Paul on the road to Damascus, for instance, would not meet these requirements.

9 Fierro states $(1964,86)$ : „Hilario identifica prácticamente ,gloria' y ,claritas' en muchas ocasiones. Traduce con ambas indistintamente los mismos textos bíblicos. Recurre tanto a una como a otra en expre- 
Jerome on Venantius Fortunatus evidence (Venantius Fortunatus, Carm. 8.1.54-60). In his commentary on Mt 17,2, Hilary qualifies the Lord's clothes as ,garments of glory' (habitus gloriae) or ,garments of brilliance' (habitus claritatis), interchanging the terms ,glory' and ,brilliance' indifferently.

In line with the references to individual body parts, their impairments, deformities, and their restoration following the resurrection - thereby implying retention of the body's complete anatomical structure in its risen state - and as a type of complement to the scenes from the Book of Job, the preacher appends the episode of Dives and Lazarus in arguing her case (Cons., PG 31, 1700C-1701A). The citation of the dialogue between Abraham and Dives (1700C-1701A), the latter's request for a drop of water to cool his tongue, and the reference to the tip of Lazarus's finger, using which this drop is to be provided, also serve as a reminder that our bodies' anatomical integrity is not compromised in the life to come. However, although the preacher's definition of the resurrection body is entirely in line with Jerome's as expounded in Contra Johannem, her definition of the ,spiritual body' is not. Jerome defines the resurrection body in constitutional terms, to wit, about its makeup, as does Origen (Contra Johannem, PL 23, 378A-B), whose understanding of the risen body's constitution Jerome needs to denounce while accusing John of Jerusalem of endorsing it. In his rebuttal to Origen's claim, Jerome offers a contrary contention but always along the lines of a compositional principle (382B). With Jerome, the corpus spirituale that rises in the resurrection, the resurrection body, is not spiritual in a sense Origen construes it, namely, ethereal, like to the breath and the breeze; it is fleshy in its structure and composition. Jerome has the full support even of Rufinus (Swete 1908, 95-96). The term "resurrection of the flesh " carnis resurrectio (89-92), is neither a scriptural term nor a phrase coined by Jerome but one that was inevitably appropriated by the Church in her effort to outwit the ,sophistries' of the Docetic Gnostics »in order to safeguard Scriptural truth " and "to protect another fundamental doctrine of the Catholic faith " (89-92). In the same context, Tertullian, De resurrectione carnis 63 (94), asserts »resurget igitur caro, et quidem omnis et quidem ipsa et quidem integra" [The flesh, therefore, will rise again, and indeed the whole, and indeed itself, and indeed unimpaired]. Jerome is therefore replying to what seems to be Origen's novelty in applying Paul's form of words corpus sprirituale to define the makeup and constituent properties of the resurrection body within the context of the broader challenge the Church faced in forming her doctrine on the nature and composition of that body. ${ }^{10}$

siones equivalentes: ,habitus gloriae' o ,habitus claritatis'. Las escribe dentro de un mismo contexto, si dar indicios de que alguna de ellas tenga peculiar significado. Las sitúa a menudo en paralelismo estricto, y emplea indiferentemente los pleonasmos ,gloria claritatis', y ,claritas gloriae'."

10 Origen's use of Paul's phrase corpus spirituale to define the resurrection body with respect to the constitution of the body seems to have arisen in light of an urgency forced upon him primarily by the pressure of non-Christian and heretical parties to determine the nature of the risen body; see, for instance, his discussion with Celsus on this subject (Swete 1908, 93); as regards deviant Christian views and grossly simplistic opinions commonly entertained by members of the Church on that issue, see Contra Johannenm (PL 23, 375C). 
Jerome does not object to or question Origen's reading of corpus sprituale in constitutional terms; he merely answers based on Origen's definitional presuppositions in order to refute his opponent's conclusions; which conclusions had been reached in part by a strictly qualified, if not fanciful, interpretation of the term ,spiritual' applied exclusively to the makeup of the resurrection body against the tradition in which Jerome stood along with Tertullian and possibly also with Clement of Rome (89-91). The approach in Cons. is entirely different on this point. As previously stated, although in all other respects Cons. fully abides by the tradition in which Contra Johannem and Jerome stand for the nature and makeup of the resurrection body, it approaches the application of Paul's phrase, spiritual body' to the risen body from a completely different perspective. Either indirectly calling into question this phrase's application strictly to the resurrection body's makeup or by way of merely offering a different interpretation, Cons. does not construe, spiritual body' in structural or makeup terms but interprets it with a quickening or enlivening principle in mind, namely, the Holy Spirit; it reads: "our present body is a soulish body, to wit, a body that depends on the soul, thanks to which we stay alive in our present existence; but that which rises again is a spiritual body because it is reborn through the Holy Spirit." (Cons., PG 31, 1702A) This is not an unprecedented interpretation of Paul's corpus spirituale. It occurs in later patristic literature, both Eastern and Western, and John the Evangelist already points out the enlivening power of the Holy Ghost according to the Lord's statement (Jn 6,63: "It is the spirit that quickened: the flesh profited nothing "). St. John Chrysostom speaks in like manner, stating that even in its present existence, to wit, in this present life, the body is to some extent spiritual on account of the Holy Spirit's dwelling in it; but that it is not presented consistently so because the Spirit's activity within it is blocked on account of sin so that although the Spirit is present, the life of the flesh is still conditioned by the soul (Homiliae XLIV in epistolam primam ad Corinthios; In epist. I ad Cor. homil. XLI, PG 61, 359). However, the earliest reading in resurrectional literature disputing the legitimacy of Origen's understanding of ,spiritual body' in makeup terms seems to occur in Methodius of Olympus' De resurrectione and with that reading of ,spiritual body', the corresponding one in Cons. shows striking affinity. ${ }^{11}$

In summary, Cons. is a sermon that belongs with the resurrectional homiletic tradition, since its central theme revolves around the question of the resurrection body to comfort a particular class of disabled people who seem utterly mystified, confused, and deeply tormented about their resurrectional future. Cons. appears to be occasionally laced with verbal echoes, such as forms of words and phrases, as well as with units of textual structural components, such as scriptural passages, textual features, and keyword themes, bearing a suggestive affinity - now more palpable, now more subtle - to kindred works, primarily to Jerome's Contra Johannem. It is common knowledge that Jerome's Contra Johannem mainly engages what St. Jerome claimed to be Origen's misconceptions on the nature of the resurrection body.

11 For the fact that St. Radegundis of Poitiers was highly likely perita utriusque linguae and that she could read Greek in the original as well, see Synodinos 2010. 
Additionally, the affinity which the present study alleges between Contra Johannem and Cons. reveals the latter's alignment with Jerome's presuppositions on the resurrection of the flesh. In that sense, St. Radegundis of Poitiers, the author of Cons., may be said to solicit support from anti-Origenist resurrection literature in arguing her case against the overly bizarre views that her disabled audience of lepers entertained on the resurrection body when it came to the resurrection of their own. It is, therefore, distinctly possible that the preacher implements this strategy alarmed at some concrete mortiferam suspicionem she entertains, some affinity or connection she detects, or is aware of, between the convictions of her audience and a kind of mitigated Origenism. Such an affinity or connection is not explicitly stated or spelt out in so many words either because concrete evidence is lacking or for some other reason.

\section{Abbreviations}

Cons. - ps.-Basil, De consolatione in adversis [Synodinos 2010]. GCS - Griechischen Christlichen Schriftsteller.

MGH AA - Monumenta Germaniae Historica: Auctorum Antiquissimi.

PG - Patrologia Graeca.

PL - Patrologia Latina.

\section{References}

\section{Primary Sources}

Bonwetsch, Nathaniel, ed. 1917. Methodius: De resurrectione. GCS 27. Leipzig: Hinrichs'sche Buchhandlung.

Leo, Fridericus, ed. 1881. Venantius Honorius Clementianus Fortunatus: Opera Poetica. MGH AA 4. Berlin: Weidmann.

Synodinos, Christus, ed. 2010. A Critical Edition of Ps-Basil De consolatione in adversis with Introduction. PhD dissertation. Boston University.

\section{Secondary sources}

Fierro, Alfredo. 1964. Sobre la gloria en San Hilario: Una sintesis doctrinal sobre la noción bíblica de ,doxa'. Roma: Libreria editrice dell'Università Gregoriana.

Hoekema, Anthony A. 1979. The Bible and the Future. Grand Rapids: Eerdmans Publishing.

John Chrysostom. 1889. Homilies on the Epistles of Paul to the Corinthians; Homily 41 on First Corinthians. Trans. Talbot W. Chambers. Nicene and Post-Nicene Fathers, First Series, vol. 12. Buffalo, NY: Christian Literature Publishing Co.

Kennedy, H. A. A. 1897. The Expositor's Greek Testament. Vol. 3, The Epistle to the Philippians. New York; London: Hodder and Stoughton.

Mensch, James. 2019. Non-Useless Suffering. Bogoslovni vestnik 79, no. 2:315-322. https://doi. org/10.34291/bv2019/02/mensch

Scobie, Chris J. 2011. A Deliberative Rhetorical Critical Approach to the Structure and Argument of 1 Corinthians. Bogoslovni vestnik 71, no. 3:411-424.

Scott, Thomas, Matthew Henry, and William Jenks. 1865-1866. The comprehensive commentary on the Holy Bible; Containing the Text According to the Authorized version, with Marginal References, Containing Matthew Henry's Commentary. Vol. 3, Acts; Revelation. Philadelphia: J. B. Lippincott \& Co.

Swete, Henry Barclay. 1908. The Apostles' Creed: Its relation to Primitive Christianity. Cambridge: Cambridge University Press. 